\title{
Soluble Expression, Protein Purification and Quality Control of Recombinant Porcine Interferon-a
}

\author{
Jun ZHAO 1,2,3† Hai-yang YU ${ }^{2 \dagger}$ Lin GAN 2,3 Yu ZHAO 1,3 \\ Shu-qi LI ${ }^{1,3}$ Xiu-le FU 1,3 Ming-li WANG ${ }^{1,2,3 *}$ \& Jason CHEN ${ }^{2,4}$ \&
}

† Jun Zhao and Hai-yang Yu contributed equally to this study and should be considered as co-first authors

' Wuhu Overseas Students Pioneer Park, Wuhu, Anhui Province, 241000, CHINA

${ }^{2}$ Department of Microbiology, Anhui Medical University, Hefei, Anhui Province, 230032, CHINA

${ }^{3}$ Anhui JiuChuan Biotech Co., Ltd, Wuhu, Anhui Province, 241007, CHINA

${ }^{4}$ Department of Pathology \& Cell Biology, Columbia University, New York, 10032, USA

Article Code: KVFD-2017-17372 Received: 04.02.2017 Accepted: 29.05.2017 Published Online: 30.05.2017

Citation of This Article

Zhao J, Yu HY, Gan L, Zhao Y, Li SQ, Fu XL, Wang ML, Chen J: Soluble expression, protein purification and quality control of recombinant porcine interferon-a. Kafkas Univ Vet Fak Derg, 23 (5): 825-829, 2017. DOI: 10.9775/kvfd.2017.17372

\begin{abstract}
Herein, we reported an Escherichia coli-based expression and purification method of recombinant porcine interferon alpha (rPolFN- $a)$. PolFN- $a$ coding sequence was cloned into PMD18-T vector and then subcloned into pET-32a (+) vector using standard recombinant DNA techniques and the resulting plasmid was transformed into BL21(DE3) competent cells. After induction with isopropyl- $\beta$-D-1-thiogalactopyranoside (IPTG), rPolFN- $a$ was purified from the supernatant of the bacteria lysate using a simple two-step chromatography process consisting of a $\mathrm{Ni}^{2+}$ affinity chromatography and a DEAE anion exchange chromatography. rPolFN-a was purified to $>95 \%$ homogeneity with a yield of $48 \mathrm{mg} / \mathrm{L}$ of culture. It has isoelectic point of 6.09 and bacterial endotoxin was less than $1 \mathrm{EU} / \mathrm{mg}$. N-terminal amino acid sequence and the peptide map digested by trypsin provided additional evidence for the authenticity of rPoIFN- $a$. The biological activity of $r$ PoIFN- $a$ was $1.1 \times 10^{6} \mathrm{IU} /$ $\mathrm{mL}$ in HEp-2/Vesicular Stomatitis Virus (VSV) titration system and its specific activity reached to $1.0 \times 10^{6} \mathrm{IU} / \mathrm{mg}$. In conclusion, we obtained high-level expression of a soluble form of bioactive rPoIFN-a by using pET-32a (+) prokaryotic expression system.
\end{abstract}

Keywords: Soluble expression, Protein purification, Quality control, Porcine interferon-a, Vesicular Stomatitis Virus (VSV)

\section{Rekombinant Domuz İnterferon-a'nın Çözünür Ekspresyonu, Protein Saflaştırması ve Kalite Kontrolü}

\section{Özet}

Bu sunuda rekombinant domuz interferon alfa (rPolFN-a)'nın Escherichia coli-temelli ekspresyonu ve saflaştırma metodu rapor edilmiştir. PoIFN-a kodlayan sekansı pMD18-T vektör içine klonlandı ve sonrasında standart rekombinant DNA teknikleri kullanılarak pET-32a (+) vektör içine subklonlandı ve elde edilen plazmid BL21(DE3) kompetan hücreler içine nakledildi. İzopropil- $\beta$-D-1-tiogalaktopiyranosid (IPTG) ile uyarmanın ardından rPolFN- $a$, bakteri lizatının süpernatantından basit iki basamaklı kromatografi işlemi ( $\mathrm{Ni}^{2+}$ affinite kromatografi ve DEAE anyon değişim kromatografi) kullanılarak saflaştıııldı. rPolFN-a $48 \mathrm{mg} / \mathrm{L}$ kültür oluşumu ve $>95 \%$ homojenite ile saflaştııılı. Ürün 6.09 izoelektrik puanına sahip olup bakteriyal endotoksin $1 \mathrm{EU} / \mathrm{mg}$ 'dan daha azdý. $\mathrm{N}$-ucu amino asit sekansý ve tripsin ile olupturulan peptit haritasý rPolFN-a'nın özgünlüğü hakkında ilave kanýt saðladý. rPolFN-a'nın biyolojik aktivitesi HEp-2/ Vesicular Stomatitis Virus (VSV) titrasyon sisteminde $1.1 \times 10^{6} \mathrm{IU} / \mathrm{mL}$ olarak tespit edilirken spesifik aktivitesi $1.0 \times 10^{6} \mathrm{IU} / \mathrm{mg}^{\prime}$ a ulaştı. Sonuç olarak, pET-32a (+) prokaryotik ekspresyon sistemi kullanılarak biyoaktif rPoIFN-a'nın çözünür formunun yüksek derecede ekspresyonu sağlandı.

Anahtar sözcükler: Çözünür ekspresyon, Protein saflaştırma, Kalite Kontrol, Domuz interferon-a, Vesicular Stomatitis Virus (VSV)

\section{INTRODUCTION}

Among type I Interferons (IFNs), IFN-a plays important roles in inhibition of viral replication ${ }^{[1]}$. Previously, recombinant IFN-a has been successfully expressed in prokaryotes, eukaryotes and baculovirus ${ }^{[2-4]}$. However, the function of the E. coli expressed products was constrained by protein misfolding ${ }^{[3]}$. The protein expressed in Pichia

\section{8 iletişim (Correspondence)}

+86-551-65123422 (Wang ML), +1-212-305-3310 (Chen J) Fax: 86-551-65123422 (Wang ML), +1-212-305-1262 (Chen J) microbio@ahmu.edu.cn (Wang ML), jc28@cumc.columbia.edu (Chen J) 
was readily degradable. The baculovirus expression system does not sustain continuous high level expression.

In the present study, we represented the expression, purification, and quality control scheme for producing bioactive rPolFN- $a$ in large scale. It will facilitate the biological research and clinical application of porcine IFN-a.

\section{MATERIAL and METHODS}

\section{Bacterial Strains, Reagents and Cell Lines}

Molecular biology reagents were purchased from TaKaRa Biotech (TaKaRa, Dalian, China). The $\mathrm{Ni}^{2+} \mathrm{His}$-bind resin and DEAE -Sepharose $\mathrm{Cl} 6 \mathrm{~B}$ column were obtained from $\mathrm{GE}$ Healthcare (Piscataway, NJ, USA). The mouse anti-PoIFN-a monoclonal antibody was purchased from Abcam (ab11408, Abcam, Cambridge, UK). The pET-32a (+) vector, E. coli $\mathrm{DH} 5 \mathrm{a}$, E. coli BL21 (DE3), and HEp-2 cell line were preserved in our laboratory.

\section{Porcine IFN-a cDNA Cloning}

Total RNA was extracted from peripheral white blood cells of a 6-month-old Bamei pig and was then reverse transcribed to cDNA. The primer sequences for RT-PCR of PolFN-a (NCBI accessing number AY345969) were 5'-GGAATTCATGTGTGACCTGCCTCAG-3' (forward) and 5'-CTCGAGTCACTCCTTCTTCCTGAGT-3' (reverse) which included EcoRI and Xhol sites (underlined). The amplification length was $501 \mathrm{bp}$, and It did not include the signal peptide sequence. The RT-PCR product was cloned into PMD-18T vector and the resulted recombinant plasmid was further confirmed by PCR and DNA sequencing, The final product was named as pMD18T-PolFN-a.

\section{Expression Vector Construction}

The inserted PolFN- $a$ gene in pMD18T-PolFN-a was digested by EcoR I and Xho I, and was then ligated into the pET-32a (+) plasmid. The authenticity, orientation and reading frame of the recombinant plasmid pET-32a (+)-PolFN-a was verified by DNA sequencing.

\section{Expression of PolFN-a Protein}

The plasmid pET-32a (+)-PolFN-a was transformed into competent E. coli BL21 (DE3). The bacteria were cultured in $\mathrm{LB}$ medium at $37^{\circ} \mathrm{C}$ to a density of $\mathrm{OD}_{600}=0.6$. After $4 \mathrm{~h}$ induction by IPTG, the bacteria were collected and resuspended in lysis buffer for sonication The lysate was then centrifuged and the supernatant and pellet were collected separately ${ }^{[5]}$.

\section{Purification of rPolFN-a Protein}

The rPolFN-a protein in the supernatant of cell lysate was purified with Chelating Sepharose Fast Flow $\mathrm{Ni}^{2+}$ chromatography (GE Healthcare, Piscataway, NJ, USA) following the protocol from the manufacturer. The chromatogram were shown in Fig. 2A and Fig. 2 B.

\section{Determination of Protein Concentration and Purity}

The protein concentration was determined by the Bradford method ${ }^{[6]}$. Reversed-phase high-performance liquid chromatography (RP-HPLC) analysis was used to determine the purity of the purified rPolFN-a product. The integrity and specificity of the purified proteins were demonstrated by Western blot assay.

\section{Mass Spectrometry Analysis}

The purified protein was further analyzed by matrixassisted laser desorption/ionization time-of-flight mass spectrometer (MALDI-TOF MS). Mass analysis was performed using a Voyager DE-STR Biospectrometry ${ }^{\mathrm{TM}}$. Workstation (Applied Biosystems, Foster City, CA, USA).

\section{Determination of rPolFN-a Biological Activity}

A cytopathic effect inhibition based IFN-a bioassay ${ }^{[7]}$ was used to evaluate the ability of the recombinant protein to protect HEp-2 cells from VSV infection. Data were expressed as mean unit $(U) / \mathrm{mL}$, where 1 unit of IFN- $\alpha$ activity was defined as the reciprocal of the dilution producing $50 \%$ inhibition of CPE. The titer of sample IFN, was determined by the Reed-Muench method as previously described ${ }^{[8]}$.

\section{Other Quality Control Measurement of rPolFN-a}

The peptide map, isoelectric point, endotoxin, ultraviolet spectroscopy, and $\mathrm{N}$-terminal amino acid sequencing of rPolFN-a were all determined according to the guidelines in Veterinary Pharmacopoeia of People's Republic of China (2010 edition) ${ }^{[9]}$.

\section{RESULTS}

\section{Soluble Expression of Recombinant Protein pET-32a (+)-PoIFN-a}

The rPolFN-a protein was over expressed as shown by a dominant band of $35.0 \mathrm{kDa}$ in Coomassie blue stained PAGE gel (Fig.1A). Besides, the over-expressed protein in the E. coli culture was found majorly in the supernatant, not in the pellet (Fig.1B). By SDS-PAGE analysis, the expressed recombinant protein contituted to $32 \%$ of the total cellular protein, or $48 \mathrm{mg} / \mathrm{L}$ in E. coli culture.

\section{Purification of pET-32a (+)-PoIFN-a Protein}

In the supernatant of cell lysate, it was shown a single protein peak by $\mathrm{Ni}^{2+}$ affinity chromatography (Fig. 2A) and by DEAE anion exchange chromatography (Fig. 2B). The result of purification by HPLC showed that there was a dominant protein peak with purity of $95.5 \%$ (Fig. 


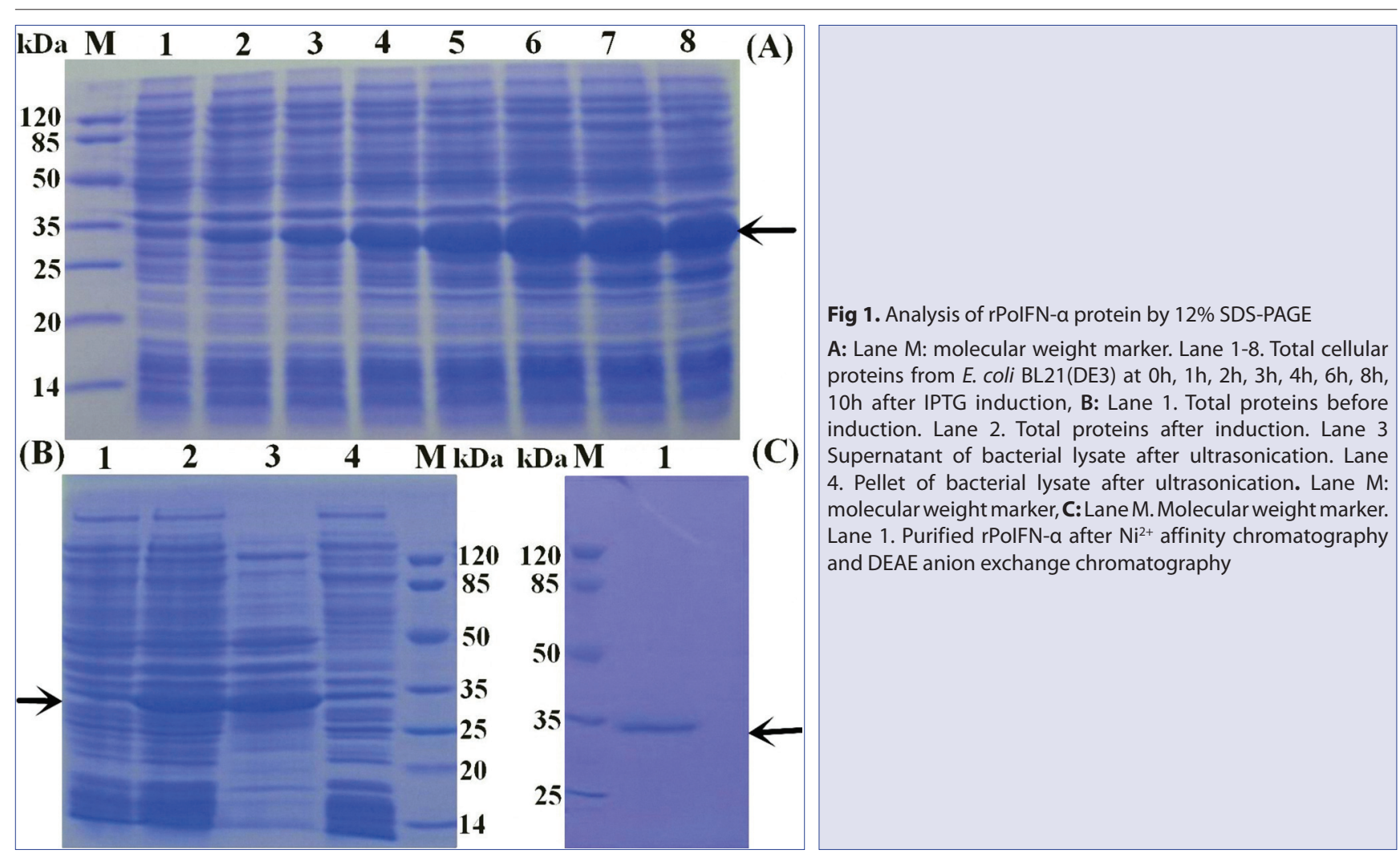

Fig 2. Protein characterization
by affinity chromatography, anion
exchange chromatography, HPLC
and Western blot
A: Ni ${ }^{2+}$ affinity chromatography
with absorbance at 280 nm, B:DEAE
anion exchange chromatography
with absorbance at 280 nm, C:
HPLC examination of purified
proteins. The peak is the target
protein which was detected at a
wavelength of 280 nm, D: Western
Blot analysis of purified proteins.
Lane M. Molecular weight marker.
Lane 1. Purified rPolFN-a protein
without enterokinase digestion.
Lane 2. Purified rPolFN-a with
enterokinase digestion. Lane 3 .
Total cellular proteins before
induction
and
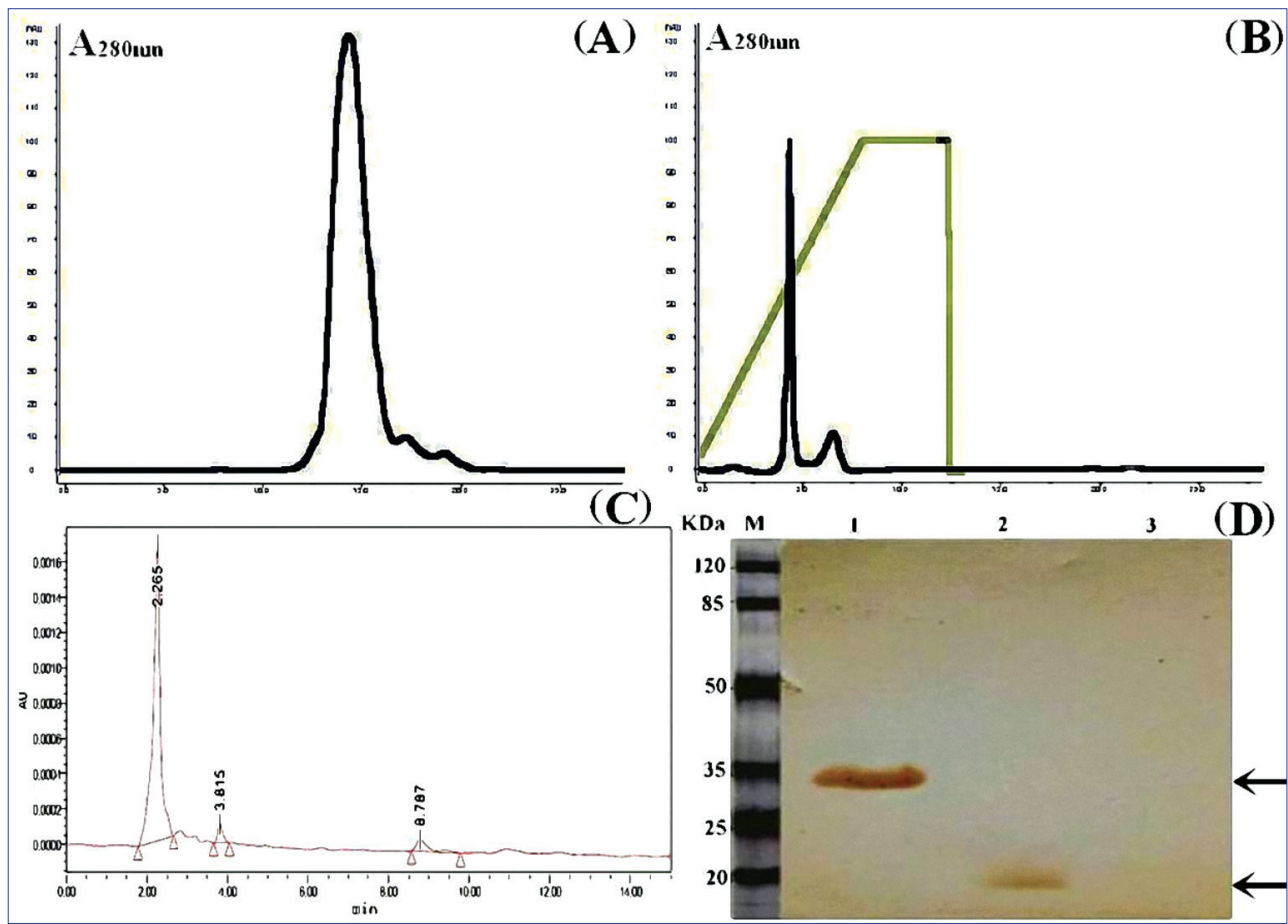

2C). Western blot analysis with anti-PolFN-a monoclonal antibody showed a non-enterokinase digested protein product at $35 \mathrm{kDa}$ (Fig. 2D) and a enterokinase digested PolFN-a protein at $19.3 \mathrm{kDa}$ (Fig. 2D), consistent with that in SDS-PAGE gel (Fig. 1C).

The purification chart of rPolFN- $a$ from $300 \mathrm{~mL}$ of bacterial culture showed that the recombinant rPolFN- $a$ was purified to 4.9 fold by the two-step purification procedure and its specific activity reached to $1.0 \times 10^{6} \mathrm{IU} / \mathrm{mg}$ (Table 1-A).

\section{Bioactivity of Purified rPolFN- $a$}

The results showed that HEp-2 cells pretreated with $1 \mathrm{U}$ of purified rPolFN inhibited $50 \%$ of VSV infection 


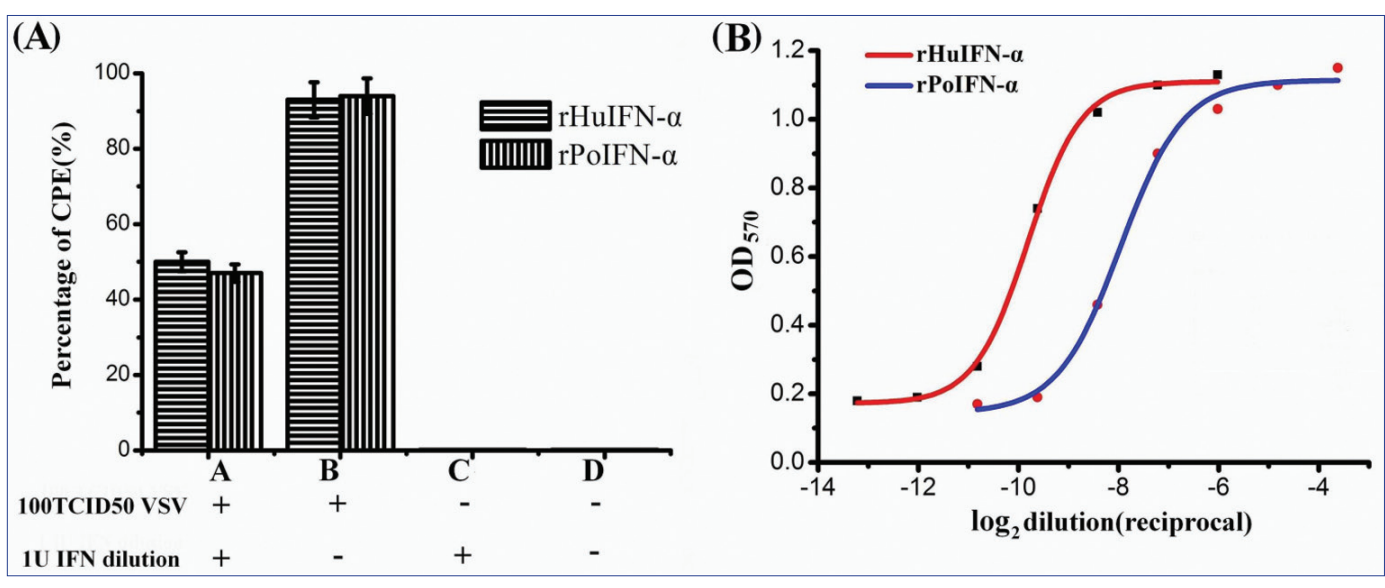

Fig 3. Antiviral activity of the rPolFN- $a$ in HEp-2/VSV titration system

A: $50 \%$ of CPE inhibition by 1 unit of rPolFN- $a$ and 1 unit of rHulFN- $a$ and the control groups for the titration of biological activity of IFN, A: about 50\% CPE was observed in VSV infected cells pre-incubated with 1 unit of IFN-a, B: about $90 \%$ CPE was observed in VSV infected cells without IFN-a treatment, C: No CPE was observed in the cells pre-incubated with 1 unit of IFN-a without VSV infection, D: No CPE was observed in the cells which was treated with neither VSV infection nor IFN- $a$ addition. B: The dose-response curve of interferon in HEp-2/VSV system. The figure shows that the titre of rHulFN- $a$ is slightly higher than that of rPolFN- $a$ in human cells

Table 1-A. Purification chart of rPoIFN-a from $300 \mathrm{~mL}$ of bacterial culture*

\begin{tabular}{|l|c|c|c|c|}
\hline Purification Step & Total Protein $(\mathbf{m g})$ & Total Activity (IU) & Specific Activity (IU/mg) & Fold of Purification \\
\hline Before purification (Cell Lysate) & 77.9 & $1.6 \times 10^{7}$ & $2.0 \times 10^{5}$ & 1.0 \\
\hline After two-step purification & 14.5 & $1.4 \times 10^{7}$ & $1.0 \times 10^{6}$ & 4.9 \\
\hline * Results were representative of three independent experiments
\end{tabular}

Table 1-B. Quality control of the bulk of rPolFN- $a$

\begin{tabular}{|l|l|l|l|}
\hline Category & Method & Specification & Reference \\
\hline Specific activity & HEp-2/VSV & $\geq 1.0 \times 10^{6} \mathrm{IU} / \mathrm{mg}$ & \\
\hline Purity & SDS-PAGE and HPLC & $\geq 95.0 \%$ & Ref. ${ }^{[9]}$, Appendix 36,41 \\
\hline Bacterial endotoxin & LAL(Limulus Amebocyte Lysate) & $<1 \mathrm{EU} / \mathrm{mg}$ & Ref. $^{[9]}$, Appendix 130 \\
\hline Isoelectic point & Isoelectrofocusing & $6.09($ within $4.5 \sim 6.5)$ & Ref. $^{\left[{ }^{[9}\right.}$, Appendix 41 \\
\hline UV maximum & UV scan & $(278 \pm 3) \mathrm{nm}$ & Ref. $^{[9]}$, Appendix 26 \\
\hline Peptide map & Tryptic digestion & Conformed to reference & Ref. $^{\left[{ }^{[9]}\right.}$, Appendix 107 \\
\hline N-terminal amino acid sequence & Edman degradation & CDLPQTHSLAHTRAL & Ref. $^{\left[{ }^{[9},\right.}$, Appendix 32 \\
\hline
\end{tabular}

(Fig. $3 A$ ). The antiviral activity of the final rPolFN- $a$ protein was determined as $1.1 \times 10^{6} \mathrm{IU} / \mathrm{ml}$ by the bioactivity assay. The inhibitory activity of rPolFN-a on VSV replication in culture was dose dependent. The doseresponse curve of interferon in HEp-2/VSV system was shown in Fig. $3 B$.

\section{Study on Quality Control of rPolFN-a}

The primary structure of purified rPolFN-a was confirmed by N-terminal sequencing and Mass Spectrometry analysis (Table 1-B). Also, the recombinant molecules appeared to be homogenous by reversed-phase HPLC analysis and gel filtration (Fig. 2C) with no signs of aggregation (data not shown). The results of rPolFN- $a$ analysis of quality control are summarized in Table 1-B.

\section{DISCUSSION}

In the production of recombinant protein in heterologous expression systems, solubility is a key issue. Soluble recombinant proteins are usually properly folded, functional and they are much easier to be purified than aggregated proteins obtained from inclusion bodies.

The $\mathrm{pET}$ is one of the most powerful systems yet developed for the expression of the recombinant proteins in E. coli. The pET32 series were fused with the 109 amino acid $\operatorname{Tr} \times \cdot \mathrm{Tag}^{\mathrm{TM}}$ thioredoxin protein which is a solubilization tag that assists in the proper folding of the expressed peptides and keeps them from precipitating. This vector also contains cleavable His.Tag ${ }^{\circledR}$ and $\mathrm{S} \cdot \mathrm{Tag}^{\mathrm{TM}}$ sequences for detection and purification. Through the use of combination 
of pET-32a (+) vector and BL21(DE3) host cell, the desired expression product can comprise more than $30 \%$ of the total cell proteins in a few hours after induction ${ }^{[5]}$.

In summary, the present study demonstrated that a functional porcine IFN-a protein was expressed in $E$. coli in a soluble form. The recombinant protein was readily purified by a two-step chromatographic procedure. Its authenticity and bioactivity were verified by multiple tests of quality control. This protein could be further expected for mass production and clinical applications of rPolFN-a.

\section{Acknowledgements}

The research was supported by the research programs of The National Spark Program of China, (No. 2013GA710060 and No. 2014GA710014) and the programs from the Scientific Support Project of Anhui Province Education Department (No. KJ2012ZD08, KJ2012Z162) and The Innovtion Fund Technology Based Firms in China (No. 12C26213403428)

\section{REFERENCES}

1. Taylor KE, Mossman KL: Recent advances in understanding viral evasion of type I interferon. Immunology, 138, 190-197, 2013. DOI: 10.1111/imm.12038

2. Wang YB, Wang ZY, Chen HY, Cui BA, Wang YB, Zhang HY, Wang R: Secretory expression of porcine interferon-gamma in baculovirus using HBM signal peptide and its inhibition activity on the replication of porcine reproductive and respiratory syndrome virus.Vet Immunol Immunopathol, 132, 314-317, 2009. DOI: 10.1016/j.vetimm.2009.05.017

3. Lefèvre $F$, L'Haridon $R$, Borras-Cuesta $F$, La Bonnardière $C$ : Production, purification and biological properties of an Escherichia coliderived recombinant porcine alpha interferon. J Gen Virol, 71, 1057-1063, 1990. DOI: 10.1099/0022-1317-71-5-1057

4. Yu R, Dong S, Zhu Y, Jin H, Gao M, Duan Z, Zheng Z, Shi Z, Li Z: Effective and stable porcine interferon-alpha production by Pichia pastoris fed-batch cultivation with multi-variables clustering and analysis. Bioprocess Biosyst Eng, 33, 473-483, 2010. DOI: 10.1007/s00449009-0356-3

5. Liu ZQ, Yang PC: Construction of pET-32 a (+) Vector for Protein Expression and Purification. N Am J Med Sci, 4, 651-655, 2012. DOI: 10.4103/1947-2714.104318

6. Kruger NJ: The Bradford method for protein quantitation. Methods $\mathrm{Mol}$ Biol, 32, 9-15, 1994. DOI: 10.1385/0-89603-268-X:9

7. Armstrong JA: Cytopathic effect inhibition assay for interferon: Microculture plate assay. Methods Enzymol, 78, 381-387, 1981. DOI: 10.1016/0076-6879(81)78145-X

8. Reed LJ, Muench H: A simple method of estimating 50 percent end points. Am J Hyg, 27, 493-497, 1938. DOI: 10.1093/oxfordjournals.aje.a118408

9. Commission of Chinese Veterinary Pharmacopoeia: Veterinary Pharmacopeia of the People's Republic of China. 2010 edn., Part I, Appendix 26-130, China Agriculture Press, Beijing, 2010. 